\title{
Rebound of plasma viremia following cessation of antiretroviral therapy despite profoundly low levels of HIV reservoir: implications for eradication
}

\author{
Tae-Wook Chun ${ }^{a}$, J. Shawn Justement ${ }^{\mathrm{a}}$, Danielle Murray ${ }^{\mathrm{a}}$, Claire W. Hallahan ${ }^{\mathrm{a}}$, Janine \\ Maenza $^{\mathrm{b}}$, Ann C. Collier ${ }^{\mathrm{b}}$, Prameet M. Sheth ${ }^{\mathrm{c}}$, Rupert Kaul ${ }^{\mathrm{c}}$, Mario Ostrowski ${ }^{\mathrm{c}}$, Susan Moir ${ }^{\mathrm{a}}$, \\ Colin Kovacs ${ }^{\mathrm{C}}$, and Anthony S. Fauci ${ }^{\mathrm{a}}$ \\ aNational Institute of Allergy and Infectious Diseases, National Institutes of Health, Bethesda, \\ Maryland ${ }^{b}$ Department of Medicine, University of Washington School of Medicine, Seattle, \\ Washington, USA 'Department of Medicine, University of Toronto, Toronto, Ontario, Canada
}

\begin{abstract}
Objectives-Sustained suppression of plasma viremia in HIV-infected individuals is attainable with antiretroviral therapy (ART); however, eradication of virus that would allow discontinuation of ART has been hampered by the persistence of HIV reservoirs. It is of great interest to identify individuals who had received ART for prolonged periods of time with extremely low or undetectable HIV reservoirs and monitor plasma viremia following discontinuation of therapy.
\end{abstract}

Methods-We measured the size of HIV reservoirs in $\mathrm{CD}^{+} \mathrm{T}$ cells of individuals on long-term ART and monitored plasma viremia following cessation of ART in one individual with an exceptionally low viral burden after a decade of therapy.

Results-We demonstrated undetectable levels of HIV DNA in the blood of eight of 45 infected individuals on long-term ART. Among those eight individuals, the frequency of cells carrying infectious virus was significantly lower in those who initiated ART during the early versus the chronic phase of infection. One individual with undetectable HIV DNA in both blood and tissue and a profoundly low level of infectious virus experienced plasma viral rebound 50 days following discontinuation of ART.

Conclusions-Our data suggest that a significant reduction in the size of viral reservoirs may be achievable in selected individuals who initiate standard ART early in infection. However, given re-emergence of plasma viremia in an individual with an extraordinarily low viral burden, therapeutic strategies aimed at specifically targeting these extremely rare HIV-infected cells with novel interventions may be necessary in order to achieve eradication of virus.

\section{(C) 2010 Wolters Kluwer Health | Lippincott Williams \& Wilkins}

Correspondence to Tae-Wook Chun, PhD, Laboratory of Immunoregulation, National Institute of Allergy and Infectious Diseases, National Institutes of Health, Building 10, Room 6A32, 9000 Rockville Pike, Bethesda, MD 20892, USA. Tel: +1 301 496 0890; fax: +1 301402 5920; twchun@nih.gov.

Author contributions: T.-W.C. and A.S.F designed research, T.-W.C., D.M. and J.S.J. performed research, T.-W.C, C.W.H, and S.M. analyzed data, J.M., A.C.C., P.M.S, R.K., M.O., and C.K. provided research materials, and T.-W.C. and A.S.F. wrote the paper.

Potential conflicts of interest: A.C.C. has received research grants from Boehringer-Ingelheim, Hoffman-La Roche, Gilead Sciences, Schering-Plough, and Tibotec-Virco, and consulted for Glaxo-Smith-Kline, Tibotec-Virco, and Pfizer. 


\section{Keywords}

antiretroviral therapy; discontinuation of therapy; eradication; human immunodeficiency virus; viral reservoirs

\section{Introduction}

Despite the development of successful therapeutic strategies [1], it has thus far been impossible to eradicate HIV in infected individuals receiving effective antiretroviral therapy (ART), mainly due to the persistence of viral reservoirs [2-4]. Previous studies have demonstrated the persistence of HIV in $\mathrm{CD}^{+} \mathrm{T}$ cells in blood as well as in gut-associated lymphoid tissue (GALT) of infected individuals receiving ART who had maintained undetectable levels of plasma viremia for significant periods of time [5], an observation that may help explain the relatively rapid rebound of plasma viremia upon treatment interruption [6,7]. In this regard, it has been demonstrated that detectable levels of plasma viremia $(>50$ copies of HIV RNA per ml) re-emerge on average 9 days following discontinuation of ART in individuals who experienced ART-induced suppression of plasma viremia [7]. However, the vast majority, if not all, of such infected individuals carried readily detectable HIV reservoirs prior to cessation of ART and had received antiretroviral drugs for less than 3-5 years [6,7]. Although viral reservoirs, which persist in spite of clinically effective ART, pose a major impediment to complete eradication of virus, evidence for continual decay of a pool of infected $\mathrm{CD}^{+} \mathrm{T}$ cells has also been demonstrated in a subset of HIV-infected individuals, especially those who initiated ART during the early phase of infection [8,9]. In this regard, it would be of interest to determine if treatment with ART for extended periods of time (up to and longer than a decade) could bring the viral reservoirs to extremely low and possibly undetectable levels, and whether under such conditions the occurrence, timing, and level of viral rebound would be influenced upon discontinuation of therapy. We conducted the present study to address this issue.

\section{Materials and methods}

\section{Patient population}

Forty-four individuals with documented HIV infection who had received ART for a median of 7.7 years (range 3.0-10.5) and who had achieved prolonged suppression of plasma viremia were studied. One of 44 patients had been reported in a previously published paper [9]. Nine of the 44 individuals initiated ART during the early phase of infection ( $<6$ months after acquisition of HIV). All participants included in this study maintained undetectable levels of plasma viremia ( $<50 \mathrm{copies} / \mathrm{ml})$ without viral 'blips' after initiation of ART as determined by frequent blood sampling (at least three times per year). Any individual with detectable plasma viremia ( $>50$ copies $/ \mathrm{ml}$ ) during the course of ART was excluded from this study. Blood and tissue specimens were collected from the study participants in accordance with protocols approved by the Institutional Review Boards of the University of Toronto, Toronto, Canada, University of Washington, Seattle, and by the Office of Human Subjects Research at the National Institutes of Health.

\section{Isolation of $\mathrm{CD}^{+} \mathrm{T}$ cells in blood and preparation of cells in gut-associated lymphoid tissue}

Peripheral blood mononuclear cells (PBMCs) were obtained from blood draw and leukapheresis by Ficoll-Hypaque density gradient centrifugation. $\mathrm{CD} 4^{+} \mathrm{T}$ cells were isolated from PBMCs of HIV-infected individuals using either a column-based cell or an automated separation technique (StemCell Technologies) as previously described [10]. The purity of 
enriched CD $4^{+} \mathrm{T}$ cells was generally greater than $95 \%$ assessed by flow cytometry. In order to examine cells in GALT, sigmoidoscopy was conducted in two study participants. Tissue samples ( $>10$ biopsies) were incubated with $0.5 \mathrm{mg} / \mathrm{ml}$ collagenase (Type II-S; Sigma) in RPMI containing 5\% fetal bovine serum, HEPES, and Pen/Strep at $37^{\circ} \mathrm{C}$ for $30 \mathrm{~min}$. After frequent pipetting and vortexing, cells were washed and stored on ice and the remaining undigested tissue was treated with $1.0 \mathrm{mg} / \mathrm{ml}$ collagenase for an additional $30 \mathrm{~min}$. The cells obtained above were subjected to $\mathrm{CD} 8^{+}$cell depletion (Invitrogen-Dynal).

\section{Quantitative real-time PCR for measurements of HIV DNA}

In order to determine the frequency of $\mathrm{CD}^{+} \mathrm{T}$ cells carrying HIV proviral DNA in infected individuals, realtime PCR was carried out on genomic DNA isolated from 1-2 $\times 10^{6}$ purified $\mathrm{CD}^{+} \mathrm{T}$ cells using the Puregene DNA isolation kit according to the manufacturer's specifications (Gentra). $1 \mu \mathrm{g}$ of DNA was then used as a template for real-time PCR in an iCycler (Bio-Rad). The amplification reaction was carried out in triplicate using $0.5 \mu \mathrm{mol} / \mathrm{l}$ primers, $0.2 \mu \mathrm{mol} / \mathrm{l}$ fluorescent probe, $0.8 \mathrm{mmol} / \mathrm{l} \mathrm{dNTPs}, 5 \mathrm{mmol} / 1 \mathrm{MgCl}_{2}$, and $2.5 \mathrm{U}$ Platinum Taq Polymerase (Invitrogen) in $50 \mu 1$ total volume. The following primers were used: 5'-GGTCT CTCTGGTTAGACCAGAT-3' (5' primer) and 5'-CTG CTAGAGATTTTCCACACTG-3' (3' primer) along with the fluorescent probe 5'-6FAMAGTAGTGTGTGCCCGTCTGTT-TAMRA-3'. PCR conditions consisted of a denaturation step at $95^{\circ} \mathrm{C}$ for $3 \mathrm{~min}$ followed by 45 cycles of $15 \mathrm{~s}$ at $95^{\circ} \mathrm{C}$ and $1 \mathrm{~min}$ at $59^{\circ} \mathrm{C}$. Serially diluted ACH-2 DNA $(40000,8000,1600,320,64,12.8,2.56$, and 0.56 cell equivalents per well in triplicates) was also subjected to the above PCR to obtain standard curves. The detection limit of the assay was 2.6 copies of HIV DNA. In order to determine the frequency of HIV infection in GALT, approximately 200000 CD8-depleted cells were lyzed in 10 $\mathrm{mmol} / \mathrm{l} \mathrm{Tris}-\mathrm{HCl} \mathrm{pH} 8$ containing $100 \mu \mathrm{g} / \mathrm{ml}$ proteinase K (Roche Applied Science) for $1 \mathrm{~h}$ at $56^{\circ} \mathrm{C}$ followed by heat inactivation of the enzyme. Real-time PCR specific for human $\beta$ actin DNA (Applied Biosystems) was carried out on the above cell lysates in order to determine the exact copy number of cells per $\mu 1$ of cell lysate. Serially diluted ACH-2 DNA was also subjected to the above PCR to obtain standard curves. Finally, real-time PCR specific for HIV DNA was carried out as described above and the copy number of HIV DNA per $1 \times 10^{6} \mathrm{CD}^{+} \mathrm{T}$ cells was calculated based on the results obtained from the PCR experiments.

\section{High-input quantitative coculture assays}

In order to determine the frequency of $\mathrm{CD} 4^{+} \mathrm{T}$ cells carrying replication-competent $\mathrm{HIV}$, high-input quantitative coculture assays were carried out in which multiple wells containing $1 \times 10^{7} \mathrm{CD}^{+} \mathrm{T}$ cells were subjected to activation in 12-well tissue culture plates as described previously [11]. Briefly, highly enriched $\mathrm{CD}^{+} \mathrm{T}$ cells were enumerated using an automated cell counter (Guava PCA, Guava Technologies) and precisely $10 \times 10^{6} \mathrm{CD}^{+} \mathrm{T}$ cells were seeded to each well in 12 -well plates. Subsequently, $8 \times 10^{6}$ irradiated PBMCs from HIV-negative healthy donors were added to each well along with anti-CD3 antibody and incubated overnight in the presence of culture medium including recombinant IL-2 (20 units $/ \mathrm{ml}) .1 \times 10^{6} \mathrm{CD} 8$-depleted and anti-CD3 stimulated PBMC blasts from HIV-negative donors were added to each well the following day and again on day 7 . The cultures were subjected to removal of $33 \%$ of the cell suspension every three days and replenished with fresh media. The culture supernatants were subjected to HIV p24 ELISA between days 14 and 21 . The viability of cultures was periodically measured using dyes that stain cell membrane and DNA (Guava PCA, Guava Technologies). The infectious units per million cells (IUPM) values from the high-input coculture (HIC) assays were determined as described [2] except that the Newton-Raphson algorithm with a convergence criteria of relative change of the estimated IUPM value less than $1 \times 10^{-6}$ was used. When high-HICs 
were negative, the IUPM value was estimated to be lower than a number that assumes that one well containing 10 million cells was indeed culture-positive.

\section{Determination of plasma viremia following discontinuation of antiretroviral therapy}

Plasma viral loads were monitored longitudinally using a branched DNA assay (the limit of detection of 50 copies of HIV RNA per ml) after one study participant voluntarily discontinued all antiretroviral drugs.

\section{Results}

In order to determine the frequency of $\mathrm{CD}^{+} \mathrm{T}$ cells carrying HIV DNA from the study participants, genomic DNA was prepared from highly purified $\mathrm{CD}^{+} \mathrm{T}$ cells and subjected to real-time PCR specific for HIV proviral DNA (limit of detection 2.6 copies of HIV DNA per $\mu \mathrm{g}$ of genomic DNA or 150000 cell equivalent) [10]. The median copy number of HIV proviral DNA for all study participants examined was 417.1 (range <2.6-8804.4) per $10^{6}$ $\mathrm{CD} 4^{+} \mathrm{T}$ cells (Fig. 1a). The median copy number of HIV proviral DNA in the study participants who had initiated ART within 6 months of infection was significantly lower (4.6 copies per $10^{6} \mathrm{CD} 4^{+} \mathrm{T}$ cells) compared to those who had initiated ART during the chronic phase of infection ( 949.4 copies per $10^{6} \mathrm{CD}^{+} \mathrm{T}$ cells $)(P=0.003)$. Of note, no measurable HIV proviral DNA was detected in four of nine early treated (44.4\%) and four of 35 chronic treated $(11.4 \%)$ individuals.

In order to examine the frequency of $\mathrm{CD} 4^{+} \mathrm{T}$ cells carrying infectious virus, a $\mathrm{HIC}$ assay [11], which allows examination of large numbers of cells, was conducted using highly enriched $\mathrm{CD}^{+} \mathrm{T}$ cells from the eight infected individuals in whose cells no measurable HIV proviral DNA had been detected. As shown in Fig. 1b, infectious virus was recovered in all infected individuals using the $\mathrm{HIC}$ assay on $\mathrm{CD}^{+} \mathrm{T}$ cells. In one particular individual, the first HIC assay involving $3 \times 10^{8}$ purified $\mathrm{CD}^{+} \mathrm{T}$ cells failed to produce replicationcompetent virus ( 7.6 years after initiation of ART). The infectious viral burden was estimated to be below 0.0012 per $10^{6} \mathrm{CD}^{+} \mathrm{T}$ cells, using the assumption that one additional well would have resulted in HIV p24-positive outcome. However, a subsequent HIC assay conducted 10.5 years after initiation of ART using $1.56 \times 10^{9} \mathrm{CD}^{+} \mathrm{T}$ cells resulted in one out of 156 wells being positive for infectious virus. This translated into an infectious viral burden of 0.00064 per $10^{6} \mathrm{CD} 4^{+} \mathrm{T}$ cells or one infected cell per $1.7 \times 10^{9} \mathrm{CD} 4^{+} \mathrm{T}$ cells. This is the lowest infectious HIV burden recorded to date in our laboratory and is considerably lower than the previously reported average frequency of 0.059 infectious units per $10^{6} \mathrm{CD} 4^{+} \mathrm{T}$ cells in HIV-infected individuals having received ART for more than 7.6 years [10]. When the coculture data were stratified by time of initiation of ART, the frequency of cells carrying infectious virus in infected individuals who initiated therapy within 6 months of infection was significantly lower (median: 0.0074 infectious units per $10^{6} \mathrm{CD}^{+} \mathrm{T}$ cells, range 0.00064-0.0173) than that of infected individuals who initiated therapy during the chronic phase of infection (median 0.0666 infectious units per $10^{6} \mathrm{CD} 4^{+}$ T cells, range $0.0345-0.0847)(P=0.03)$.

Colonoscopy was performed on two infected individuals in order to measure levels of HIV in GALT. As shown in Table 1, real-time PCR conducted on CD8-depleted cells from sigmoid colon biopsies from one infected individual (who initiated ART during the chronic phase of infection) in whom HIV proviral DNA was undetectable in peripheral blood CD4 ${ }^{+}$ T cells, but in whom infectious virus was recovered, revealed readily detectable HIV DNA (89 copies of DNA per million cells). However, HIV DNA was undetectable in CD8depleted cells isolated from the sigmoid colon biopsies of the infected individual (who initiated ART during the early phase of infection) in whom HIV proviral DNA was undetectable and the level of infectious virus was extraordinarily low (one infected cell per 
$1.7 \times 10^{9} \mathrm{CD}^{+} \mathrm{T}$ cells) in peripheral blood $\mathrm{CD} 4^{+} \mathrm{T}$ cells (Table 1 ), suggesting that a profound reduction in the size of viral reservoir was achieved in this study participant.

In order to investigate whether discontinuation of ART in the individual who was started on ART early in the course of infection and who had an extraordinarily low HIV reservoir would result in rebound of plasma viremia, and what the kinetics of such a rebound would be if it occurred, we discontinued ART in the patient upon his consent and monitored plasma viremia. As shown in Fig. 2, plasma viremia was not detected for the first 50 days following discontinuation of therapy. Subsequently, plasma viremia rebounded to 1593 copies of HIV RNA per ml followed by spontaneous suppression to an undetectable level. However, plasma viremia then rebounded again to 8684 copies of HIV RNA per ml on day 143 at which point ART was re-initiated.

\section{Discussion}

The persistence of HIV proviral DNA and/or infectious virus in $\mathrm{CD}^{+} \mathrm{T}$ cells of infected individuals receiving ART and in whom plasma viremia was suppressed below the level of detection for prolonged periods of time has thus far made the prospect of eradicating virus extremely problematic $[2-4,10]$. In the present study, we demonstrated undetectable levels of HIV DNA in the blood of eight infected individuals on long-term ART, including one individual in whom HIV proviral DNA could not be detected in the GALT and infectious HIV burden was extraordinarily low. Among the eight individuals whose peripheral blood $\mathrm{CD}^{+} \mathrm{T}$ cells had undetectable HIV DNA, the frequency of cells carrying infectious virus was significantly lower in those in whom ART was initiated during the acute/early phase of infection compared to those who began therapy during the chronic phase of infection. It is not clear whether differential decay rates of virus in subsets of memory $\mathrm{CD} 4^{+} \mathrm{T}$ cells [12] and/or efficacy of different drug regimens contributed to rapid clearance of HIV in some infected individuals receiving ART. Although we cannot rule out the existence of low levels of HIV replication $[13,14]$ or the persistence of virus in other lymphoid tissue [5,8], our data clearly suggest that, at least in a subset of infected individuals, the profound suppression of viral replication by long-term effective ART that had been initiated early in the course of infection may lead to substantially greater reduction of residual HIV compared to those in whom ART was initiated after HIV infection had already been established as a chronic process. Of note, it is likely that a standard quantitative coculture assay would not have detected any replication competent virus in one study participant, given the unusually large number of cells (over one billion $\mathrm{CD} 4^{+} \mathrm{T}$ cells) used to detect one well containing infectious $\mathrm{HIV}$ in the $\mathrm{CD} 4^{+} \mathrm{T}$ cells. Nonetheless, the present study clearly demonstrated that the combination of early initiation of ART, an extended duration of therapy, and a profoundly low HIV burden in $\mathrm{CD} 4^{+} \mathrm{T}$ cells did not eradicate HIV, nor did it indefinitely suppress the re-emergence of plasma viremia; however, it did lead to a longer period (50 days) of aviremia compared to previous studies (average 9 days) after cessation of antiretroviral drugs [7]. It is possible that profoundly low HIV burden and/or HIV-specific immune responses may have contributed to the long delay of plasma viral rebound in this infected individual [15]. The secondary plasma viral rebound may have been due to emergence of escape mutants [16]. Our data also suggest that the vast majority of, if not all, infected individuals receiving ART will experience plasma viral rebound regardless of the level of $\mathrm{HIV}$ in their $\mathrm{CD}^{+} \mathrm{T}$ cell compartment at the time of discontinuation of ART.

Several attempts have been made in the past to 'flush' out HIV from $\mathrm{CD} 4{ }^{+} \mathrm{T}$ cells in infected individuals receiving ART without providing definitive evidence for eradication of virus $[6,17,18]$. Of note, we have previously demonstrated that co-administration of IL-2 and ART could lead to a dramatic diminution in the size of the $\mathrm{CD}^{+} \mathrm{T}$-cell viral reservoir [11]. Yet, despite the diminution in the size of the viral reservoir, HIV proviral DNA was 
still readily detectable in their $\mathrm{CD}^{+} \mathrm{T}$ cells prior to cessation of antiviral drugs. Given the presence of detectable proviral DNA, it should not have been surprising that these patients experienced rebound of plasma viremia upon discontinuation of therapy [6]. However, the present study demonstrates that despite the fact that prolonged treatment with ART initiated early in the course of HIV infection resulted in undetectable levels of proviral DNA and profoundly low levels of infectious HIV in peripheral blood $\mathrm{CD}^{+} \mathrm{T}$ cells, virus still rebounded upon discontinuation of therapy. It appears that currently available antiretroviral drugs, even when initiated early in the course of infection and continued for prolonged periods of time resulting in 'undetectable' HIV DNA, do not eradicate HIV [19]. In order to achieve a condition under which HIV does not rebound for extended periods of time in the absence of ART, novel therapeutic strategies aimed at more specifically targeting these extremely rare infected cells may be necessary with or without the use of therapeutic vaccination to boost immune system control of viral rebound. In addition, prior to interrupting antiretroviral therapy in HIV-infected individuals, exhaustive laboratory assays, especially HIC assays that allow detection of infectious virus in large numbers of $\mathrm{CD}^{+} \mathrm{T}$ cells, should be conducted given rebound of plasma viremia following cessation of therapy is all but certain as long as infectious viral reservoirs are present.

\section{Acknowledgments}

We thank the study volunteers for their participation in this study. We also thank Erika Benco for her invaluable assistance in the execution of this study.

Financial support: This research was supported in part by the National Institutes of Health grants (MO1 RR-00037, AI41535, and AI57005) and the Intramural Research Program of the National Institute of Allergy and Infectious Diseases, National Institutes of Health.

\section{References}

1. Walensky RP, Paltiel AD, Losina E, Mercincavage LM, Schackman BR, Sax PE, et al. The survival benefits of AIDS treatment in the United States. J Infect Dis. 2006; 194:11-19. [PubMed: 16741877]

2. Chun TW, Stuyver L, Mizell SB, Ehler LA, Mican JA, Baseler M, et al. Presence of an inducible HIV-1 latent reservoir during highly active antiretroviral therapy. Proc Natl Acad Sci U S A. 1997; 94:13193-13197. [PubMed: 9371822]

3. Finzi D, Hermankova M, Pierson T, Carruth LM, Buck C, Chaisson RE, et al. Identification of a reservoir for HIV-1 in patients on highly active antiretroviral therapy. Science. 1997; 278:12951300. [PubMed: 9360927]

4. Wong JK, Hezareh M, Gunthard HF, Havlir DV, Ignacio CC, Spina CA, et al. Recovery of replication-competent HIV despite prolonged suppression of plasma viremia. Science. 1997; 278:1291-1295. [PubMed: 9360926]

5. Chun TW, Nickle DC, Justement JS, Meyers JH, Roby G, Hallahan CW, et al. Persistence of HIV in gut-associated lymphoid tissue despite long-term antiretroviral therapy. J Infect Dis. 2008; 197:714-720. [PubMed: 18260759]

6. Chun TW, Davey RT Jr, Engel D, Lane HC, Fauci AS. Reemergence of HIV after stopping therapy. Nature. 1999; 401:874-875. [PubMed: 10553903]

7. Davey RT Jr, Bhat N, Yoder C, Chun TW, Metcalf JA, Dewar R, et al. HIV-1 and T cell dynamics after interruption of highly active antiretroviral therapy (HAART) in patients with a history of sustained viral suppression. Proc Natl Acad Sci U S A. 1999; 96:15109-15114. [PubMed: 10611346]

8. Zhang L, Ramratnam B, Tenner-Racz K, He Y, Vesanen M, Lewin S, et al. Quantifying residual HIV-1 replication in patients receiving combination antiretroviral therapy. N Engl J Med. 1999; 340:1605-1613. [PubMed: 10341272] 
9. Chun TW, Justement JS, Moir S, Hallahan CW, Maenza J, Mullins JI, et al. Decay of the HIV reservoir in patients receiving antiretroviral therapy for extended periods: implications for eradication of virus. J Infect Dis. 2007; 195:1762-1764. [PubMed: 17492591]

10. Chun TW, Nickle DC, Justement JS, Large D, Semerjian A, Curlin ME, et al. HIV-infected individuals receiving effective antiviral therapy for extended periods of time continually replenish their viral reservoir. J Clin Invest. 2005; 115:3250-3255. [PubMed: 16276421]

11. Chun TW, Engel D, Mizell SB, Hallahan CW, Fischette M, Park S, et al. Effect of interleukin-2 on the pool of latently infected, resting CD4+ T cells in HIV-1-infected patients receiving highly active antiretroviral therapy. Nat Med. 1999; 5:651-655. [PubMed: 10371503]

12. Chomont N, El-Far M, Ancuta P, Trautmann L, Procopio FA, Yassine-Diab B, et al. HIV reservoir size and persistence are driven by $\mathrm{T}$ cell survival and homeostatic proliferation. Nat Med. 2009; 15:893-900. [PubMed: 19543283]

13. Sharkey ME, Teo I, Greenough T, Sharova N, Luzuriaga K, Sullivan JL, et al. Persistence of episomal HIV-1 infection intermediates in patients on highly active antiretroviral therapy. Nat Med. 2000; 6:76-81. [PubMed: 10613828]

14. Strain MC, Gunthard HF, Havlir DV, Ignacio CC, Smith DM, Leigh-Brown AJ, et al. Heterogeneous clearance rates of longlived lymphocytes infected with HIV: intrinsic stability predicts lifelong persistence. Proc Natl Acad Sci U S A. 2003; 100:4819-4824. [PubMed: 12684537]

15. Rosenberg ES, Altfeld M, Poon SH, Phillips MN, Wilkes BM, Eldridge RL, et al. Immune control of HIV-1 after early treatment of acute infection. Nature. 2000; 407:523-526. [PubMed: 11029005]

16. McMichael AJ, Borrow P, Tomaras GD, Goonetilleke N, Haynes BF. The immune response during acute HIV-1 infection: clues for vaccine development. Nat Rev Immunol. 2010; 10:11-23. [PubMed: 20010788]

17. Kulkosky J, Nunnari G, Otero M, Calarota S, Dornadula G, Zhang H, et al. Intensification and stimulation therapy for human immunodeficiency virus type 1 reservoirs in infected persons receiving virally suppressive highly active antiretroviral therapy. J Infect Dis. 2002; 186:14031411. [PubMed: 12404155]

18. Lehrman G, Hogue IB, Palmer S, Jennings C, Spina CA, Wiegand A, et al. Depletion of latent HIV-1 infection in vivo: a proof-of-concept study. Lancet. 2005; 366:549-555. [PubMed: 16099290]

19. Richman DD, Margolis DM, Delaney M, Greene WC, Hazuda D, Pomerantz RJ. The challenge of finding a cure for HIV infection. Science. 2009; 323:1304-1307. [PubMed: 19265012] 


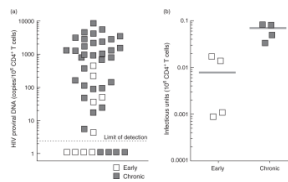

Fig. 1. Frequencies of HIV proviral DNA (a) and infectious virus (b) in CD4 ${ }^{+}{ }^{-}$cells of HIVinfected individuals receiving effective ART for prolonged periods of time

(a) Levels of HIV proviral DNA in highly enriched $\mathrm{CD}^{+}{ }^{+} \mathrm{T}$ cells was determined by realtime PCR as previously described [10]. The open and closed squares represent data obtained from the 'early treated' and 'chronic treated' individuals, respectively. (b) Levels of replication-competent $\mathrm{HIV}$ in $\mathrm{CD}^{+}{ }^{+} \mathrm{T}$ cells from infected individuals were determined by high input coculture assay as previously described [11]. The median is shown as gray bars. 


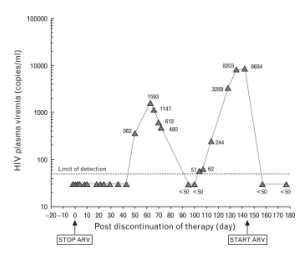

Fig. 2. Levels of plasma viremia following discontinuation and re-initiation of ART Plasma viremia was determined by a branched DNA assay with the detection limit of 50 copies of HIV RNA per ml of plasma. ARV, antiretroviral. 


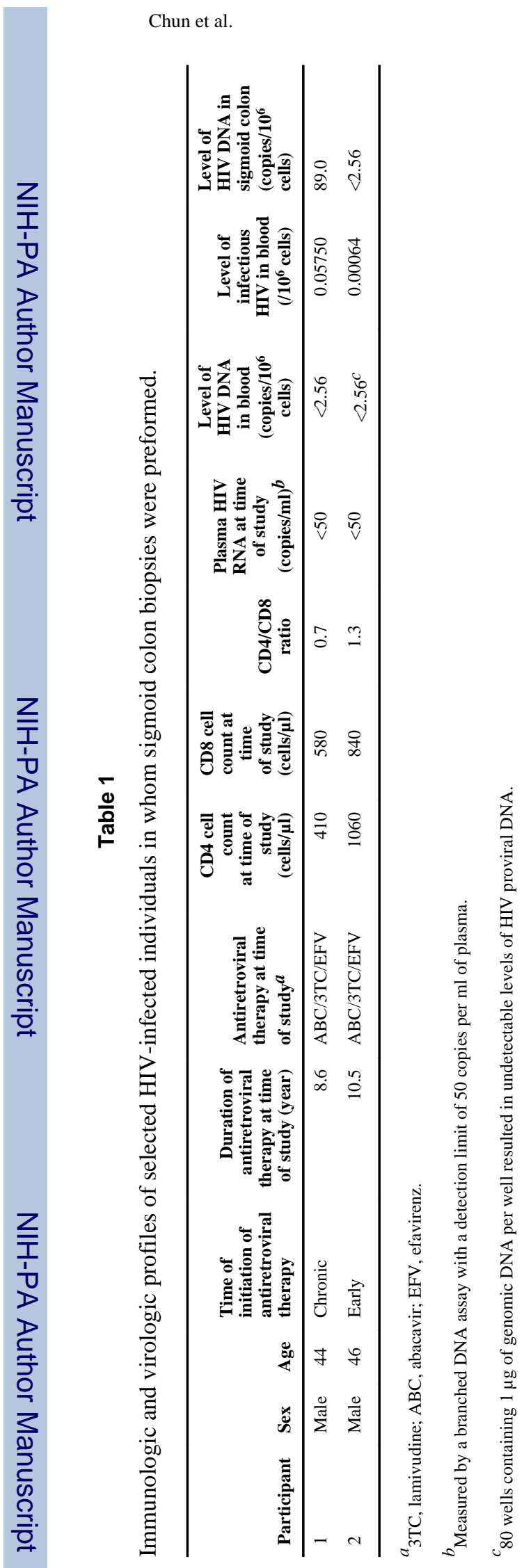

Page 10 